Bangladesh J. Zool. 42(1): 19-33, 2014

\title{
ABUNDANCE AND DIVERSITY OF AQUATIC INSECTS IN TWO WATER BODIES OF CHITTAGONG UNIVERSITY CAMPUS
}

\author{
Munira Nasiruddin*, Mohammad Ali Azadi and Md. Selim Reza \\ Department of Zoology, University of Chittagong, Chittagong 4331, Bangladesh
}

\begin{abstract}
Abundance and diversity of aquatic insects was studied in two water bodies, (a pond and a lake) of Chittagong University campus during October 2009 to September 2010. A total of 4406 insects belonging to 32 genera, under 20 families and 6 orders were recorded. In both the water bodies, the representatives of the orders Hemiptera and Odonata were the most abundant groups. During the study period highest abundance of the total insects was recorded in November 2009 and the lowest in July 2010. Abundance of insects was comparatively higher in the pond habitat than in the lake. The Quotient of Similarity (QS) of the insects between the two water bodies was found to be the highest in October 2009 and lowest in July 2010. Species diversity, species richness and species evenness values of the lake were higher than that of the pond. Hydrophilus sp. and Sphaerodema sp. were the most dominant insects in the pond, while Chironomous sp. and Gerris sp. in the lake.
\end{abstract}

Key words: Aquatic insects, abundance, diversity, pond, lake.

\section{INTRODUCTION}

Insects are the most diverse group of organisms in freshwater bodies. The principal groups of aquatic insects constitute an important part of the biota of the fresh water communities. Aquatic insects are important organisms in a water body ecosystem function. In addition to ecosystem function, aquatic insects are reliable indicators of human impact on freshwater ecosystem. Insects have proven to be a useful tool for testing ecological paradigms (Batzar and Wissinger 1996). Ecologists have recommended the use of resident organisms, such as insects, as sensitive indicator of disturbances in order to achieve and preserve the highest water quality or the diverse water resources.

A few research works has previously been done on aquatic and semi-aquatic insects in Bangladesh. Ameen and Chowdhury (1972) listed only four aquatic bugs from Dhaka city. Survey upon dragonfly nymphs was made by Chowdhury and Akhteruzzaman (1981). Some final instar larvae of common damselfly of Dhaka city were described by Ameen et al. (1982). Ameen and Nessa (1985) listed twenty three species of aquatic Hemiptera from Dhaka city. A list of 14 species of aquatic and semi-aquatic Heteroptera of Chittagong University campus was prepared by Alam et al. (1986). Descriptions of four zygopteran

*Author for correspondence: <maazadi@yahoo.com> 
larvae from Chittagong University campus were given by Chowdhury and Miah (1990). Some unpublished works on aquatic insects were done by Biswas (1984), Islam (1985), Barua (1988), Begum (1995) and Hossain (2008). A good number of research works is available on aquatic insects in different countries of the world. Important recent contributions are those of Anbalagan et al. (2004), Hsu and Yang (2005), Majumder and Gupta (2005), Dinakaran and Anbalagan (2006), Sharma et al. (2008), Thani and Phalaraksh (2008), Ohiokhioya et al. (2009) and Das and Gupta (2010). Most of the closed water bodies in Chittagong university campus are not managed habitats. The aquatic insects are easily available and have much theoretical and practical importance. But, so far, very limited attention has been paid on the aquatic and semi aquatic insect fauna of not only in the University of Chittagong but also in Bangladesh. Therefore, the present paper deals with the study of the aquatic insect fauna of two water bodies, a pond and a lake of Chittagong University campus with an aim to survey and identify the aquatic insect fauna of the two water bodies and to find the abundance and diversity of the aquatic insects.

\section{MATERIAL AND METHODS}

Methodology for collection and identification of insects: Aquatic insects were collected from two water bodies (one pond and one lake) of Chittagong University campus. The geographical positions of the pond is $22^{\circ} 29^{\prime} 10^{\prime \prime} \mathrm{N}, 91^{\circ} 47^{\prime} 52^{\prime \prime} \mathrm{E}$ and the lake is $22^{\circ} 28^{\prime} 96^{\prime \prime} \mathrm{N}, 91^{\circ} 46^{\prime} 51^{\prime \prime}$ E. Collections were made from three sites of each water body and all sites were selected at the edge. Each site was separated by approximately $15-25 \mathrm{~m}$ distance from the other site. Samplings were done once in each month from October 2009 to September 2010 between 8-9 a.m. The specimens were collected by insect drag net $\left(1 \mathrm{~mm}\right.$ mesh size, area- $625 \mathrm{~cm}^{2}$ from the surface of the marginal zone and between and within the aquatic vegetations. Ten subsequent sweeps were repeatedly made at each station and were individually taken in plastic buckets. Insects were sorted from the detritus and kept in separate labeled plastic containers containing pond water and then taken to the laboratory, whereby, the specimens were sorted and preserved in $70 \%$ alcohol in separate labeled glass vials.

The insects were identified on the basis of the external morphology and available keys (Ward and Whipple, 1959; Ross, 1959; Clegg, 1974; Needham and Needham, 1978; Chowdhury and Akhteruzzaman, 1981; Ameen and Nessa, 1985; and Rahman and Hossain, 1988).

Statistical analysis of abundance and diversity of insect population: The generic abundance (\%) and diversity indices were calculated for each sampling 
month and for overall samplings for both the water bodies. The following diversity indices of community structures were calculated.

Monthly abundance: To find out the abundance of individuals in each Order, which had been counted from all the samples, abundance was calculated as percentage of an Order, being calculated from the total number of individuals of a monthly sample in both the water bodies.

Shannon-Wiener's Species Diversity index $\left(H^{\prime}\right)$ : The simplest measure of species diversity is to count the number of species. In the present study Shannon-Wiener diversity index (Shannon and Weiner 1949) has been calculated using the following formula:

$$
H^{\prime}=-\sum_{i=1}^{s}(n i / N \log 2 n i / N)
$$

Where, $H^{\prime}=$ Species diversity

$S=$ Total number of species in the sample

$N=$ Total number of individuals of all species

$n i=$ The number of individuals of each species

Species Richness (SR): Gleason (1922) expressed species richness by the following formula which was used during the study:

$\mathrm{SR}=\mathrm{S}-1 / \log \mathrm{N}$

Where, $\mathrm{S}=$ Total number of species in a sample

$\mathrm{N}=$ Natural log of total no. of individuals of all species

Species Evenness $\left(J^{\prime}\right)$ : Species evenness $(J)$ (equatibility) was calculated using the formula of Pielou (1966): $J^{\prime}=H^{\prime} / \log _{2} S$

Where, $J^{\prime}=$ Species Evenness

$H^{\prime}=$ Species Diversity

$S=$ Number of the species

Index of Similarity: In the present study, Sorensen's (1948) method has been used. This index of similarity is as follows:

$Q S=\frac{2 c}{a+b} \times 100$

Where, Qs = Quotient of similarity

$a=$ number of species in one association

$b=$ number of species in the other association

$c=$ number of species common to both 
Community Dominance $(C D)$ : The simple community dominance index, i.e. percentage of abundance contributed by two most abundant species was calculated following the formula of McNaughton (1968):

$C D(\%)=\frac{y_{1}+y_{2}}{y} \times 100$

Where, $y_{1}=$ number of individuals of most dominant species or the rank-1 species.

$y_{1}=$ number of individuals of the $2^{\text {nd }}$ dominant species or the rank -2 species.

$y=$ Total number of individuals of all species.

\section{RESULTS AND DISCUSSION}

The list of the aquatic insects collected during the study period from the pond and the lake is cited in Table 1 . The list includes representatives belonging to six orders, six suborders, 22 families and 32 genera. The orders were: Ephemeroptera, Odonata, Hemiptera, Coleoptera, Trichoptera and Diptera. The collected ephemeropteran, odonate, dipteran and trichopteran insects were nymphs and hemipteran and coleopteran insects were adults.

A total of 4,406 aquatic insects were collected from the two water bodies, where odonate representatives were most abundant. The representatives of the orders Trichoptera and Diptera were in negligible numbers. Four genera (Ephemera sp., Hexagenia sp., Ephemerella sp. and Heptagenia sp.) of the order Ephemeroptera were identified. The genus Ephemera was also recorded by Begum (1995). The order Odonata was represented by the nymphs of both the sub orders Zygoptera and Anisoptera. Of the total odonate collection, there were five representatives of sub order Zygoptera (Lestes sp., Coenagrion sp., Nehalennia sp., Ischnura sp. and Argia sp.) and six representatives of sub order Anisoptera (Ictinogompus sp., Aeshna sp., Libellula sp., Neurocordulia sp., Pantala sp. and Nannothemis sp.). Ameen et al. (1982) described four species of damselfly larvae from Dhaka city and Chowdhury and Miah (1990) described four zygopteran larvae from Chittagong University campus. Of the recorded zygopteran nymphs Coenagrion sp. were recorded by both Ameen et al. (1982) and Chowdhury and Miah (1990), whilst Ischnura sp. was recorded only by Ameen et al. (1982). Chowdhury and Akhteruzzaman (1981) described 13 species of dragonfly larvae and amongst the recorded anisopteran nymphs only Ictinogomphus sp. and Pantala sp. were recorded by Chowdhury and Akhteruzzaman (1981). Eight genera (Notonecta sp., Buenoa sp., Nepa sp., 
Ranatra sp., Gerris sp., Hydrometra sp., Plea sp. and Sphaerodema sp.) from the order Hemiptera were identified. Most of the collected species of the order Hemiptera in the present study (Plea sp., Ranatra sp., Gerris sp., Hydrometra sp. and Sphaerodema sp.) were recorded by Ameen and Nessa (1985) and Alam et al. (1986). The four representatives (Dytiscus sp., Thermonectus sp., Laccodytes sp. and Hydrophilus sp.) belonging to the order Coleoptera were

Table 1. Aquatic insects collected during the study period from the Pond and the Lake of Chittagong University Campus

\begin{tabular}{|c|c|c|c|}
\hline Order & Suborder & Family & Genus \\
\hline \multirow[t]{4}{*}{ Ephemeroptera } & & Ephemeridae & Ephemera sp. \\
\hline & & & Hexagenia sp. \\
\hline & & Ephemerellidae & Ephemerella sp. \\
\hline & & Heptageniidae & Heptagenea sp. \\
\hline \multirow[t]{11}{*}{ Odonata } & Zygoptera & Lestidae & Lestes sp. \\
\hline & & Agrionidae & Coenagrion sp. \\
\hline & & & Nehalennia sp. \\
\hline & & & Ischnura sp. \\
\hline & & & Argia sp. \\
\hline & Anisoptera & Gomphidae & Ictinogompus sp. \\
\hline & & Aeshnidae & Aeshna sp. \\
\hline & & Libellulidae & Libellula sp. \\
\hline & & & Neurocordulia sp. \\
\hline & & & Pantala sp. \\
\hline & & & Nannothemis sp. \\
\hline \multirow[t]{8}{*}{ Hemiptera } & Heteroptera & Notonectidae & Notonecta sp. \\
\hline & & & Buenoa sp. \\
\hline & & Nepidae & Nepa sp. \\
\hline & & & Ranatra sp. \\
\hline & & Gerridae & Gerris sp. \\
\hline & & Hydrometridae & Hydrometra sp. \\
\hline & & Pleidae & Plea sp. \\
\hline & & Belostomatidae & Sphaerodema sp. \\
\hline \multirow[t]{4}{*}{ Coleoptera } & Adephaga & Dytiscidae & Dytiscus sp. \\
\hline & & & Thermonectus sp. \\
\hline & & & Laccodytes sp. \\
\hline & Polyphaga & Hydrophilidae & Hydrophilus sp. \\
\hline \multirow[t]{2}{*}{ Diptera } & Nematocera & Culicidae & Culex sp. \\
\hline & & Chironomidae & Chironomus sp. \\
\hline \multirow[t]{3}{*}{ Trichoptera } & & Brachycentridae & Brachycentrus sp. \\
\hline & & Leptoceridae & Leptocella sp. \\
\hline & & & Tricaenodes sp. \\
\hline
\end{tabular}

identified. Hydrophilus sp. was also recorded by Islam (1985), Barua (1988) and Begum (1995). From the order Diptera only two genera (Culex sp. and Chironomus sp.) were identified. These dipteran larvae were recorded by Biswas (1984) and Begum (1995). Three larval genera of the order Trichoptera 
(Leptocella sp., Triaenodes sp. and Brachycentrus sp.) were identified and Leptocella sp. and Triaenodes sp. were also recorded by Hossain (2008).

Community structure of the aquatic insects: A sum of 4,406 insects, belonging to 32 genera was collected from the two water bodies out of which 2,858 insects were collected from the pond and 1548 insects from the lake. In the pond, representatives of the order Hemiptera were the most abundant but in the lake, representatives of the order Odonata was the most abundant, comprising $50.77 \%$ and $35.98 \%$ of the total samples respectively. However, in both the water bodies, representatives of the order Trichoptera were the least dominant comprising $0.66 \%$ and $5.17 \%$ of the total collection in the pond and the lake respectively. In the pond, the second abundant order was Coleoptera followed by the orders Diptera, Odonata and Ephemeroptera comprising 14.11\%, 5.42\% and $2.76 \%$ of the total collection. In the lake, the second abundant order was Hemiptera (19.13\%) followed by Diptera (18.22\%), Ephemeroptera (15.44\%) and Coleoptera (5.16\%). Meanwhile, Odonata with 11 genera and Hemiptera with eight genera were the orders of diversity, followed by orders Ephemeroptera and Coleoptera each with four genera, whilst orders Trichoptera with three genera and Diptera with two genera were less diversified (Tables 2 and 3).

Monthly abundance of the aquatic insects: Monthly abundance of the total aquatic insect individuals was the highest in November 2009 and lowest in July 2010 in both the pond and the lake (Tables 2 and 3).

In the pond (Table 2), the abundance of specimens under the order Hemiptera was 43.30\% (October'09), 43.39\% (November '09), 53.76\% (December '09), 56.45\% (January'10), 43.64\% (February'10), 42.73\% (April'10), 49.00\% (May'10), 61.55\% (June'10), 67.76\% (July'10), 71.57\% (August'10) and 54.30\% (September'10). The order Coleoptera (40.91\%) was found to be abundant only during the month of March 2010. The highest number of aquatic insects was found in November 2009 (12.18\%), while the lowest in July 2010 (5.32\%).

In the lake (Table 3), the month wise abundance of the order Odonata was 36.42\% (October'09), 36.90\% (November'09), 38.28\% (December'09), 36.28\% (January'10), 40.54\% (February'10), 44.54\% (March'10), 38.06\% (April'10), 39.61\% (May'10), 30.30\% (July'10) and 32.11\% (September'10). In lake high abundance of Diptera was found during the months of June'10 (35.67\%) and August'10 (27.62\%).

Monthly abundance of the total aquatic insect individuals was the highest in November'09 and lowest in July'10 in the both the water bodies. The higher number of aquatic insects (2858) was collected from the pond, where several types of microhabitats with aquatic vegetations were present. On the other hand, the lesser number was collected from the lake which might be due to the 


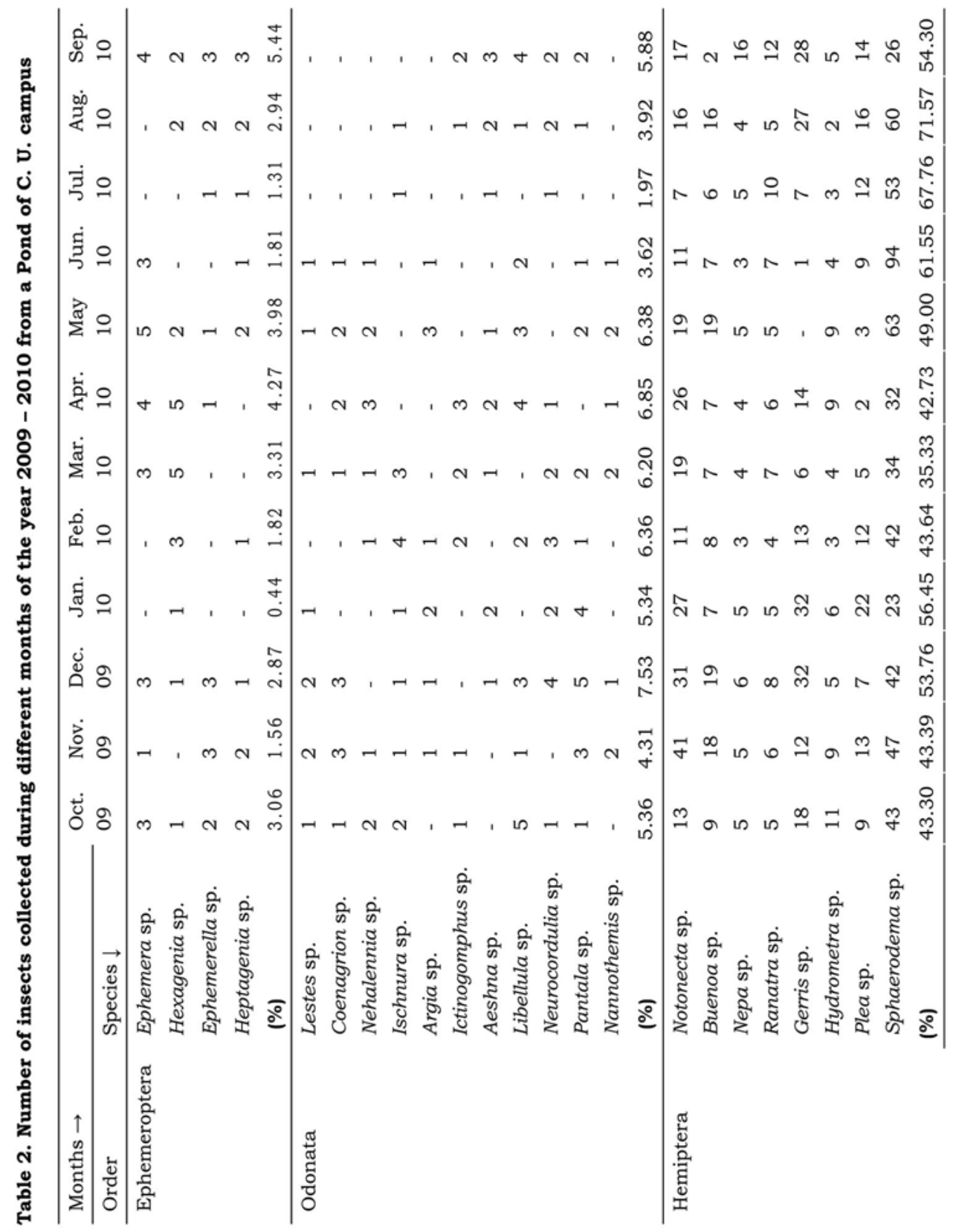




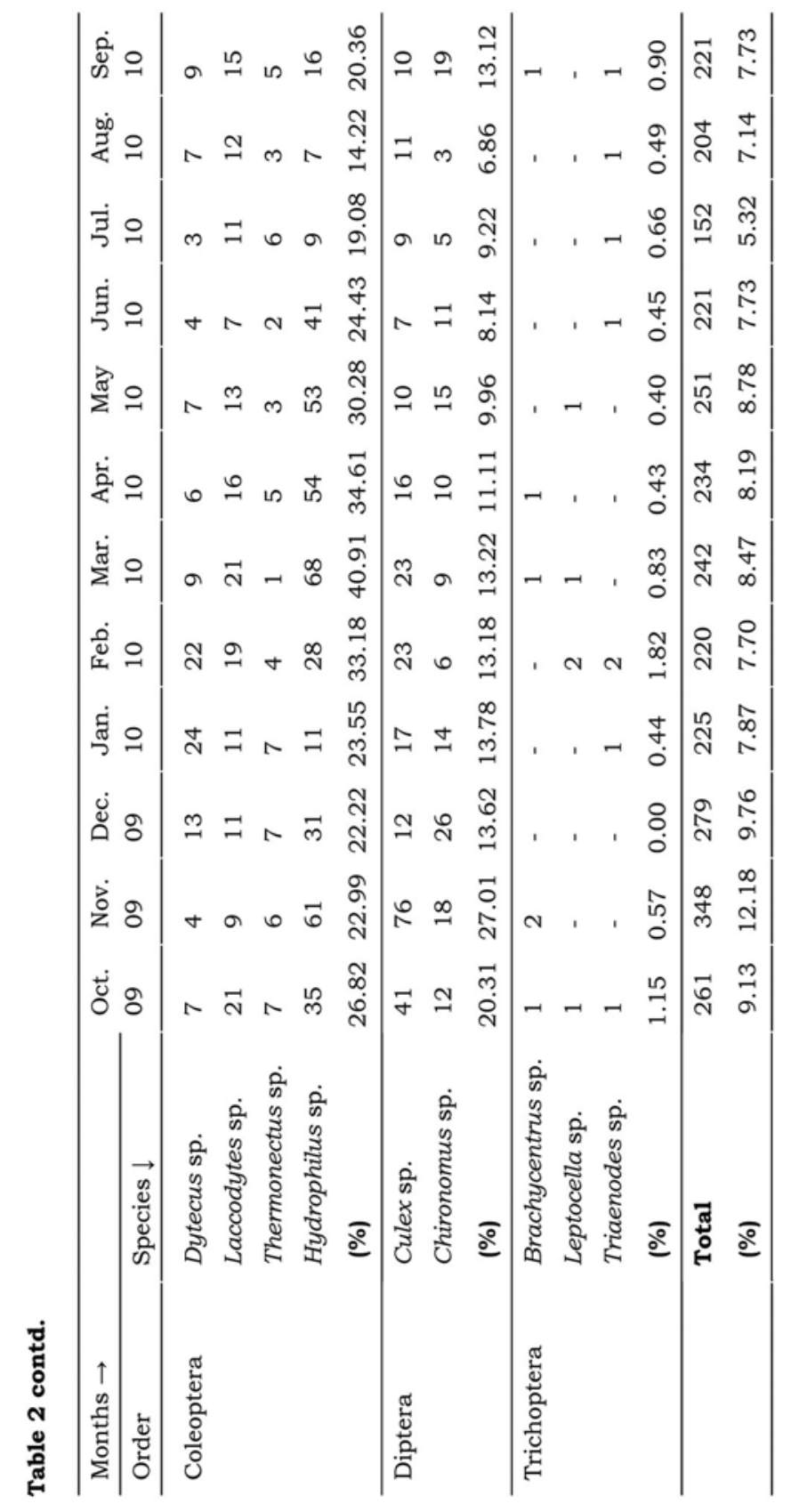




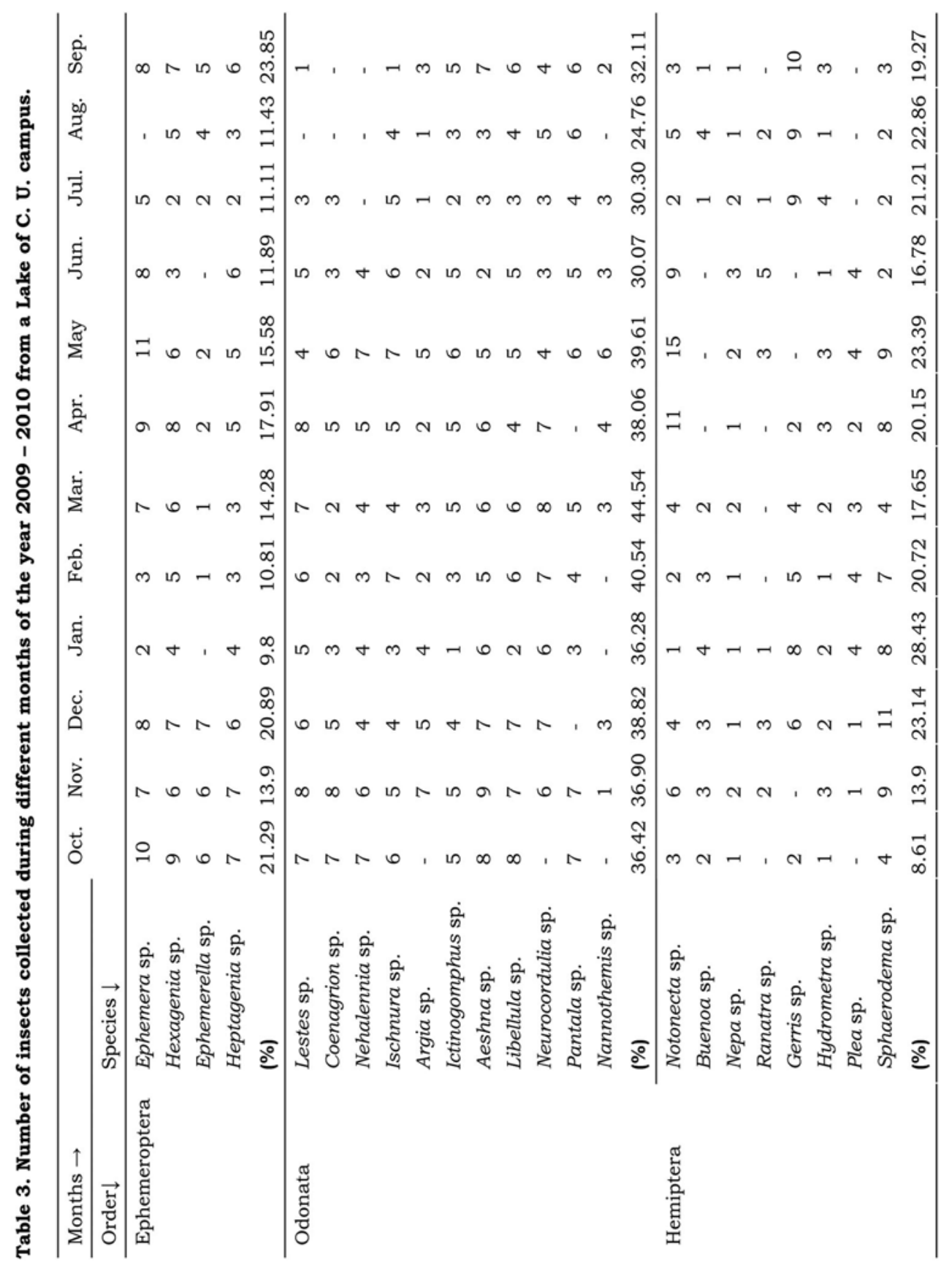




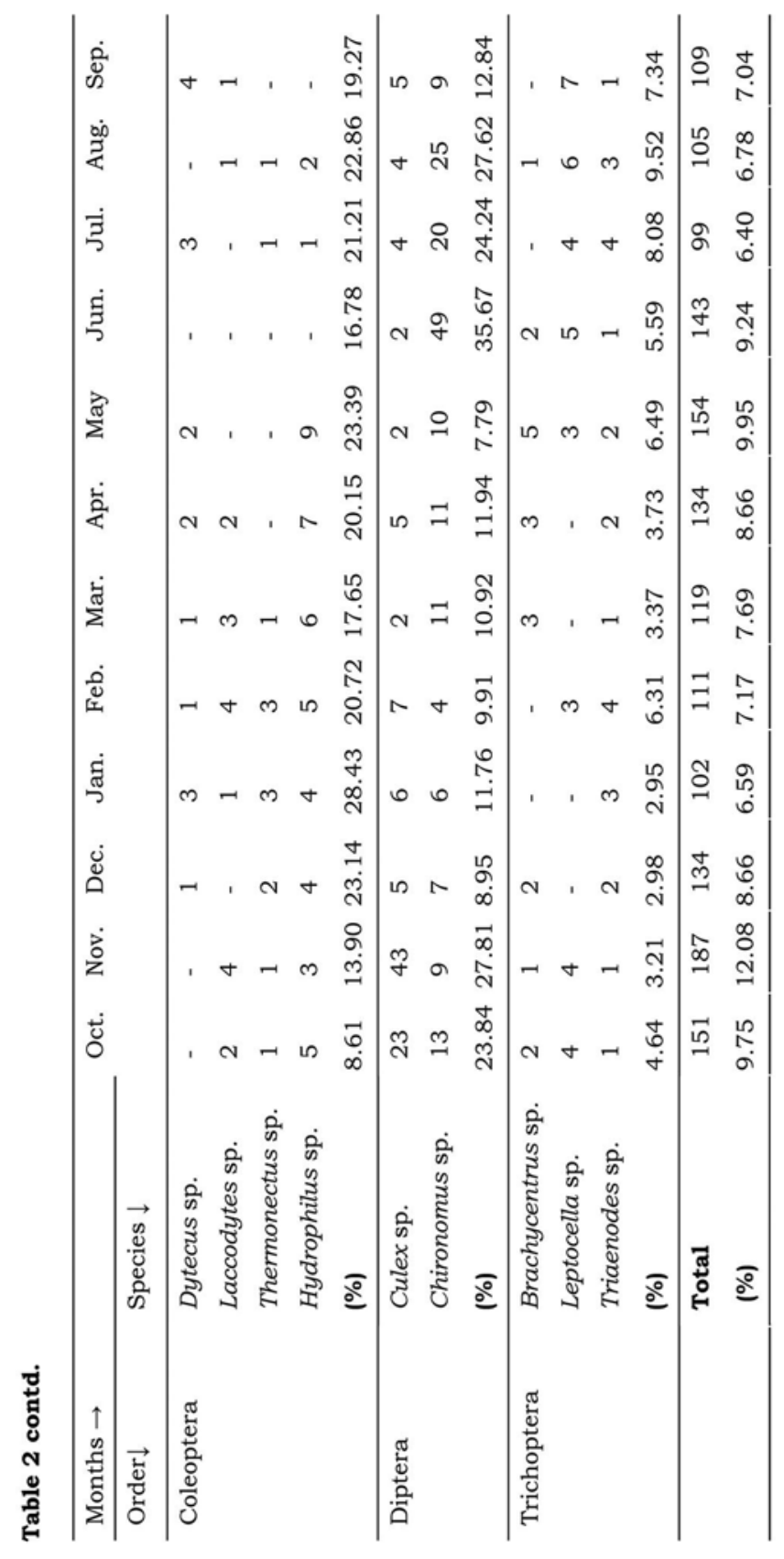


result of human interference such as fish culture and removal of the aquatic plants. Moreover, the transparency of the lake was high which was not suitable for insect's survival.

Monthly fluctuations of Species Diversity $\left(H^{\prime}\right)$, Species Richness (SR), and Species evenness $\left(J^{\prime}\right)$ of the two water bodies: Species diversity $(H)$ (Table 4$)$ of the aquatic insects in the two water bodies was found to vary from month to month. In the pond, the highest monthly species diversity value (4.10) was observed in September 2010 and the lowest (3.04) in June, 2010. However, species diversity values fluctuated between 3.43 to 3.97 during rest of the months. In the lake the highest monthly species diversity value (4.70) was observed in December, 2009 and the lowest (3.60) in June, 2010. While species diversity values fluctuated between 4.09 to 4.67 in rest of the months.

Species richness (SR) (Table 4) value of the aquatic insects was also found to be in an irregular pattern. The species richness values of aquatic insects in the pond was recorded as the highest (3.64) in March, 2010 and the lowest (2.62) in July, 2010. While species richness values fluctuated between 2.69 to 3.49 in rest of the months. The species richness values in the lake was recorded as the highest (4.21) in March, 2010 and the lowest (3.35) in June, 2010. While species richness values fluctuated between 3.45 to 4.12 in rest of the months.

Species evenness $(J)$ (Table 4 ) values also showed irregular fluctuation. The species evenness values of aquatic insects in the pond was recorded as the highest (0.88) in September, 2010 and lowest (0.66) in June, 2010 and its values fluctuated between 0.72 to 0.84 in the rest of the months. And in the lake, it was recorded as the highest (0.99) in June, 2010 and lowest (0.88) in August, 2010 and its values fluctuated between 0.88 to 0.97 in the rest of the months.

Quotient of Similarity (QS): The highest QS value (90.91) was in the month of October, 2009 and the lowest (73.47) in the month of June, 2010. The QS values fluctuated in between 75.00 to 89.80 in the rest of the months (Table 4).

The monthly community dominance (CD) of the aquatic insects: Monthly variations in the dominance index ( $\delta$ ) of aquatic insects varied from month to month. In the pond, the two most dominating insects were Sphaerodema sp. and Culex sp. in October 2009. The community dominance was $32.18 \%$ and in the lake, the most dominating insects were Chironomus sp. and Culex sp. and the community dominance was $23.84 \%$. In November, 2009, in the pond, the most dominating insects were Hydrophilus sp. and Culex sp. and the community dominance was $39.37 \%$. In the lake, the most dominating insects were Chironomus sp. and Culex sp. and the community dominance was $27.81 \%$. In 


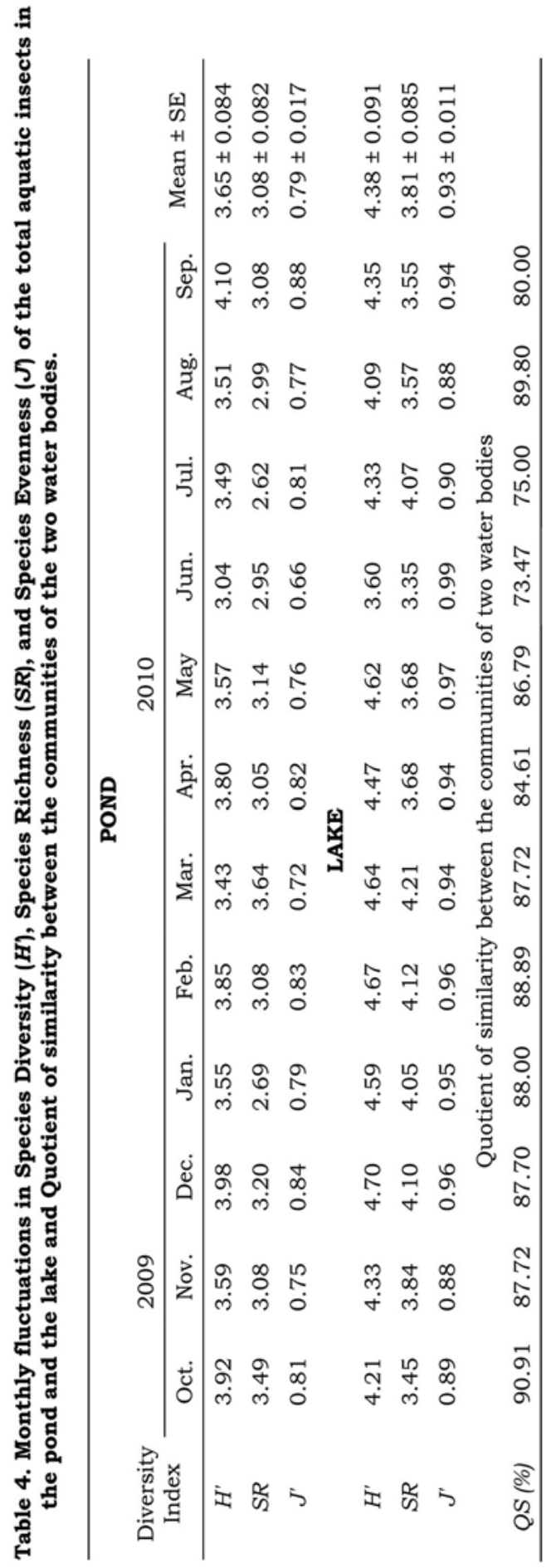


December, 2009, in the pond, the most dominating insects were Sphaerodema sp. and Gerris sp. and the community dominance was $26.52 \%$. In the lake, the most dominating insects were Sphaerodema sp. and Ephemera sp. and the community dominance was $14.18 \%$. In January, 2010, in the pond, the most dominating insects were Notonecta sp. and Gerris sp. and the community dominance was $26.22 \%$. In the lake, the most dominating insects were Sphaerodema sp. and Gerris sp. and the community dominance was $15.69 \%$. In February, March, April, May and June, 2010, in the pond, the most dominating insects were Hydrophilus sp. and Sphaerodema sp. and the community dominance ware $31.82 \%, 71.84 \%, 36.75 \%, 46.22 \%$, and $61.09 \%$ respectively. In the lake in February, 2010, the most dominating insects were Neurocordulia sp. and Sphaerodema sp. and the community dominance was $15.22 \%$; in March, 2010, they were Neurocordulia sp. and Chironomus sp. and the community dominance was 15.97; in April, 2010, they were Notonecta sp. and Chironomus sp. and the community dominance was 18.66\%; in May, 2010, they were Notonecta sp. and Ephemera sp. and the community dominance was $16.88 \%$; in June, 2010, they were Notonecta sp. and Chironomus sp. and the community dominance was 40.56\%. In July, 2010, in the pond, the most dominating insects were Sphaerodema sp. and Laccodytes sp. and the community dominance was $42.10 \%$. In the lake, they were Chironomus sp. and Gerris sp. and the community dominance was $29.29 \%$. In August, 2010, in the pond, the most dominating insects were Sphaerodema sp. and Gerris sp. and the community dominance was $42.65 \%$. In the lake, they were Chironomus sp. and Gerris sp. and the community dominance was 32.38\%. In September, 2010, in the pond, the most dominating insects were Sphaerodema sp. and Gerris sp. and the community dominance was $24.44 \%$. In the lake, they were Chironomus sp. and Ephemera sp. and the community dominance was $15.59 \%$.

In the Pond, ranking of the genera on the basis of dominance hierarchy was: Sphaerodema sp.> Hydrophilus sp.> Gerris sp.> Culex sp.> Notonecta sp. = Laccodytes sp. In the lake, ranking of the genera on the basis of dominance hierarchy was: Chironomus sp. $>$ Sphaerodema sp. $=$ Ephemera sp. $=$ Gerris sp. $=$ Notonecta sp.> Neurocordulia sp.= Culex sp.

The average species diversity of the aquatic insects was higher in the lake (4.38) than in the pond (3.65). The average species richness was high (3.81) in the lake and low (3.08) in the pond. Average species evenness value was also higher (0.93) in the lake than in the pond (0.79). The insects were quite similar in the pond and the lake. The highest similarity of the two water bodies was seen in the month of October'09 (90.91\%) and lowest similarity was seen in the month of June'10 (73.47\%). In the pond the most dominant insects were 
Sphaerodema sp. and Hydrophilus sp. The main reason of dominance might be the water quality and aquatic habitat of the pond. In the lake Chironomous sp. was the most dominant group of insects. The reason of such dominance might be due to the suitable bottom condition and favorable water quality. The low diversity in the streams, lakes or ponds may be due to reduced detritus input from the surrounding landscape. The detritus from the surrounding is an important source of food for the aquatic insects and also plays a significant role in determining the diversity (Allan 1995).

This study showed that the lake water habitat was more suitable for diversified insects. As per the mean species richness the lake hold the more aquatic insect species than the pond. The mean species evenness value was also higher in the lake than the pond. However, as per the similarity indices the insects were quite similar in both the water bodies. The study on the fauna of aquatic water body could provide valuable insights into aspects of water body ecosystem functions.

\section{LITERATURE CITED}

ALAM, M.S., AHSAN, F. and DAS, B.K. 1986. A list of aquatic and semi-aquatic heteropteran species of Chittagong University campus. Proc. Fifth Nat. Zool. Conf. Bangladesh. $163-170$ pp.

ALLAN, D.J. 1995. Stream ecology: Structure and function of running water. Madras. Chapman and Hall. $388 \mathrm{pp}$.

AMEEN, M. and CHOWDHURY, S.H. 1972. A Systematic account of the insect fauna of Dhaka city and its suburbs. Hemiptera. J. Asiatic soc. Pak. 17(1): 11-15.

AMEEN, M., AKHTER, R.U.S. and RABBI, M.F. 1982. Final instar larvae of common damselflies (Odonata : Zygoptera) of Dhaka city and their identification key. Bangladesh J. Zool. 10(2): 81-91.

AMEEN, M. and NESSA, S.K. 1985. A Preliminary identification key to the aquatic Hemiptera of Dhaka city. Bangladesh J. Zool. 13(1): 49-60

ANBALAGAN, S., KALEESWARAN, B. and BALASUBRAMANIAN, C. 2004. Diversity and Trophic categorization of aquatic insects of Courtallam hills of Western Ghats. Entomol. 29: 1-16.

BARUA, D. 1988. Studies on the relationship between the aquatic insects and physico-chemical and biological factors of a pond of Chittagong University campus. M. Sc. Project. Department of Zoology, University of Chittagong. 43 pp.

BATZER, D.P. and WISSINGER, S.A. 1996. Ecology on insect communities in non-tidal wetlands. Annual Review of Entomology 41: 75-100.

BEGUM, K. 1995. Faunistic survey of aquatic insects of some water bodies of Chittagong University campus. M. Sc. Project. Department of Zoology, University of Chittagong. $51 \mathrm{pp}$.

BISWAS, A. 1984. Some aquatic insects of Chittagong University campus and physico-chemical properties of water bodies. M. Sc. Project. Department of Zoology, University of Chittagong. $34 \mathrm{pp}$.

CHOWDHURY, S.H. and AKHTERUZZAMAN, M. 1981. Dragonfly (Odonata: Anisoptera) larvae from Chittagong. Bangladesh J. Zool. 9(2): 131-144. 
CHOWDHURY, S.H. and MIAH, M.I. 1990. Description of four Zygopteran larvae from the Chittagong University campus. Chittagong University Stud. Part.II: Sci. 14(1): 127-136.

CLEGG, J. 1974. Freshwater life. Fredrick Warne and Company Ltd. 283 pp.

DAS, K. and GUPTA, S. 2010. Aquatic Hemiptera community of agricultural fields and rain pools in Cachar District, Assam, North East India. Assam University of Science and Technology: Biological and Environmental Sciences 5(1): 123-128.

DINAKARAN, S. and ANBALAGAN, S. 2006. Seasonal variation and substrate selection of aquatic insects in a small stream in Sirumalai hills of southern Western Ghats. Journal of Aquatic Biology 21: 37-42.

GLEASON, H.A. 1922. On the relation between species and area. Ecol. 3: 156-162.

HECKMAN, C.W. 2002. Encyclopedia of the South American aquatic insects: Ephemeroptera. Kluwer Academic Publishers, Norwell, MA. 419 pp.

HOSSAIN, M. 2008. Faunistic survey of aquatic insects of Chittagong University campus with reference to some physico-chemical parameters of the water bodies. B.Sc. (Hons.) project. Department of Zoology, University of Chittagong. 47pp.

HSU, C.B. and YANG, P.S. 2005. Examining the relationship between aquatic insect assemblages and water variables by ordination techniques. Formosan Entomol. 25: 67- 85.

ISLAM, M.N. 1985. A faunistic survey and taxonomic account of the freshwater Coleopterans of Chittagong. M.Sc. Project. Department of Zoology, University of Chittagong. 23 pp.

MAJUMDAR, T.N. and GUPTA, A. 2005. Aquatic insects in the lentic systems of North Cachar Hills, Assam, India. Journal of Current Sciences 7(1): 219-224.

NEEDHAM, J.G. and NEEDHAM, P.R. 1978. A guide to the study of Freshwater Biology. Holden-day Inc. $108 \mathrm{pp}$.

McNAUGHTON, S.J. 1968. Structure and Function in California grasslands. Ecology 49: 962-972.

OHIOKHIOYA, T., IMBOOBE, T. and OHIOZEBAE, E. 2009. Pollution status of a tropical forest river using aquatic insects as indicators. African J. Ecology 48(1): 232-238.

PIELOU, E.C. 1966. The measurement of diversity in different types of Biol. Collections. J. Theort. Biol. 13: 131-144.

RAHMAN, R. and HOSSAIN M. 1988. Jalochar Keetpatanga. Bangla Academy. 328 pp.

ROSS, H.H. 1959. Introduction to aquatic insects. In Freshwater Biology. By Ward, H.B. and Whipple, G.C. Willey and Sons. New York. 902-907 pp.

SHANNON, C.E. and WIENER, W. 1949. The mathematical theory. University of Illinois press, Urbana. 117 pp.

SHARMA. A., SHARMA, R.C. and ANTHURAL, A. 2008. Surveying of aquatic insect diversity of Chandrabhaga River, Garhwal Himalayas. The Environmentalist 28(4): 395-404

SORENSEN, T. 1948. A method for establishing groups of equal amplitude in plant sociology based on similarity of species content. Danske Videnskabernes Selskab Biologiske skrifter 5: 1-34.

THANI, I. and PHALARAKSH, C. 2008. A Preliminary study of aquatic insect diversity and water quality of Mekong River, Thailand. KKU Sci. J.36 (Supplement) 95-106.

WARD H.B. and WHIPPLE, G.C. 1959. Freshwater Biology. John Willey and sons, Inc. New York. $1248 \mathrm{pp}$.

(Manuscript received on 25 September, 2013; revised on 15 March, 2014) 